\title{
Emerging oomycete threats to plants and animals
}

\author{
Lida Derevnina ${ }^{1}$, Benjamin Petre ${ }^{1}$, Ronny Kellner ${ }^{2}$, Yasin F. Dagdas ${ }^{1}$, \\ Mohammad Nasif Sarowar ${ }^{3}$, Artemis Giannakopoulou ${ }^{1}$, Juan Carlos De la \\ Concepcion $^{1}$, Angela Chaparro-Garcia ${ }^{1}$, Helen G. Pennington ${ }^{1}$, Pieter van \\ West $^{4}$, and Sophien Kamoun ${ }^{1}$ \\ ${ }^{I}$ The Sainsbury Laboratory, Norwich Research Park, Norwich, NR4 7UH, United Kingdom \\ ${ }^{2}$ Max Planck Institute for Plant Breeding Research, Cologne, 50829, Carl-von-Linné-Weg 10, Germany \\ ${ }^{3}$ Department of Fisheries Biology and Genetics, Bangladesh Agricultural University, Mymensingh, 2202, \\ Bangladesh \\ ${ }^{4}$ Aberdeen Oomycete Laboratory, Institute of Medical Sciences, University of Aberdeen, Foresterhill, \\ Aberdeen, AB25 2ZD, United Kingdom
}

Keywords: parasites, pathogens, disease, food security, agriculture, environment

\section{Summary}

Oomycetes, or water moulds, are fungal-like organisms phylogenetically related to algae. They cause devastating diseases to both plants and animals. Here, we describe seven oomycete species that are emerging or re-emerging threats to agriculture, horticulture, aquaculture, and natural ecosystems. They include the plant pathogens Phytophthora infestans, Phytophthora palmivora, Phytophthora ramorum, Plasmopara obducens, and the animal pathogens Aphanomyces invadans, Saprolegnia parasitica, and Halioticida noduliformans. For each species, we describe its pathology, importance, and impact, discuss why it is an emerging threat, and briefly review current research activities.

\section{Introduction}

Oomycetes, or water moulds, are fungal-like eukaryotes classified as stramenopiles, and which are phylogenetically grouped with diatoms and brown algae [1-4]. They are among the most problematic group of disease-causing organisms in both agriculture and aquaculture, and represent a recurrent threat for global food security. Oomycetes cause some of the most devastating plant diseases affecting crops, ornamental plants, and trees. They result in major economic losses and serious damage to natural ecosystems [5, 6]. The most notorious species are members of the genus Phytophthora, such as the late blight pathogen Phytopthora infestans, known for triggering the Irish potato famine [7].[8]. Other notable species include Phytophthora palmivora [9], causing cocoa black pod, and the sudden oak death pathogen Phytophthora ramorum, which emerged in more recent epidemics threatening native tree species [10]. Additional important oomycete plant pathogens include members of the Pythium genus and downy mildews [11, 12]. In contrast with their terrestrial counterparts, aquatic oomycetes remain understudied [3, 4]. This applies particularly to animal pathogenic oomycetes, such as Saprolegnia and Aphanomyces spp. [13]. Aquaculture has become one of the world's fastest growing food sectors, where freshwater fish dominate global aquaculture production [14]. Fish farming and fisheries provide livelihood and income for an estimated 54.8 million people, with employment 
in these sectors growing rapidly [15]. Diseases such as Epizootic Ulcerative Syndrome and saprolegniosis, caused by oomycetes, are a significant threat to the aquaculture industry [16].

\section{Why are oomycetes so successful?}

The key to pathogenic oomycetes success resides in their capacity to adapt to overcome host resistance and occasionally jump to new hosts. Various features of oomycete biology can explain their high evolutionary potential. One major driving force for their success is encompassed by their flexible mating system. Oomycetes can reproduce sexually (either homothallic or heterothallic), asexually, or through interspecific hybridization [17] enabling them to gain both allelic diversity (sexual and interspecific hybridization) and to rapidly proliferate, resulting in large population sizes (asexual/clonal populations) [18]. Large population sizes compensates for the lack of sexual recombination and increase the occurrence of spontaneous mutants with enhanced fitness [18].

Genome sequencing of oomycetes has provided additional insights into their capacity to adapt to hosts. Oomycete genomes harbor large repertoires of genes encoding virulence effectors, which modulate host processes $[19,20]$. These effector genes are typically associated with fast evolving regions of the genome, particularly in areas enriched in repeats and transposable elements, promoting genome duplication, shuffling, increased rates of mutagenesis, and gene silencing [21]. This bipartite genome organization, differentiated by slow and fast evolving regions, has led to the "two-speed" genome model, where gene-sparse repeat-rich compartments serve as a cradle for adaptive evolution, underpinning infection success by enabling the pathogen to rapidly overcome host resistance, evolve new virulence determinants, and even jump to new host species [22]. Another interesting aspect about oomycete genomes is that they exhibit variations in ploidy, and can exists as either triploids or polyploids [23-25]. The relevance of this feature is currently not fully understood, however, polyploidy has been shown to enhance vigour and buffer mutational changes by masking deleterious alleles [26], and is therefore believed to play a vital role in pathogen success. In fact, many successful P. infestans clonal lineages are made up of triploid genotypes [26].

Here, we discuss seven oomycetes that are emerging or re-emerging threats to world agriculture, horticulture, aquaculture, and natural ecosystems. They were selected based on their impact on economy and society, and include both well-known and understudied pathogens of both plants and animals. For each pathogen, we describe its pathology, importance, and impact, discuss why it is an emerging threat, and briefly review research activities that underpin effective disease management strategies. Table 1 summarizes our current knowledge of the genome, secreted protein of the examined species, and highlight why they are (re)-emerging threats.

\section{Phytophthora infestans - the Irish Potato famine pathogen}

Phytophthora infestans infects potato and tomato plants, causing late blight disease. It is infamous for triggering 
the Irish potato famine in the mid 19th century. Today, it is still a significant threat to global food security, causing severe yield losses in these crops, and economic losses of more than $\$ 6$ billion annually [27, 28] . In addition to destroying the foliage, $P$. infestans can infect tubers, which facilitates migration of the pathogen via the global seed tuber trade [29]. Current disease management strategies include chemical control and/or deployment of resistant cultivars. Resistance to agrochemicals, however, is common in epidemic causing isolates [30], and due to the pathogen adaptability, disease resistance genes are also quickly broken down and rendered ineffective [31].

Disease outbreaks are typically caused by asexually reproducing clonal lineages [24, 29, 32, 33]. These aggressive lineages dramatically reshape the population structure and become dominant over a short period of time [33,34]. For example, in Great Britain, genotype 13_A2, first detected in July 2005, surged to more than $75 \%$ of the $P$. infestans population by 2008 (Figure 1) [32]. Subsequently 13_A2 was displaced by another genotype, 6_A1, which increased in occurrence from $20 \%$ in 2010 to $80 \%$ in 2011 (http://www.fwi.co.uk/academy/lesson/potatoes-understanding-blight1). In addition, some P. infestans clonal lineages have become pandemic. 13_A2 was detected for the first time in South India in 2008, where it caused severe late blight epidemics in tomato, often resulting in 100\% crop loss [35]. The emergence of this genotype in the Indian sub-continent has led to an increase in late blight incidence on tomato and potato, with epidemics reported in subsequent years following its introduction.

P. infestans genome was sequenced in 2009 [8], which established this species as a model system, pioneering studies of oomycete effectors and evolution $[8,36]$. Notably, the study of $P$. infestans effectors have significantly moved forward our understanding of host processes targeted by the pathogen, forming strong foundations for plant-microbe interaction studies $[19,37]$. Furthermore, effectors have emerged as powerful tools to rapidly identify new resistances in potato germplasms.

\section{Phytophthora palmivora - the oomycete of tropical plants}

Phytophthora palmivora is a plant pathogen that infects more than 200 plant species in the tropics, including dicots and monocots [7]. Economically important hosts include cocoa, coconut, pineapple, rubber tree, durian, citrus, papaya, and oil palm. Disease outbreaks in these crops impact the livelihood and nutrition of millions of people globally. Annual losses due to diseases caused by P. palmivora, such as oil palm bud rot and cocoa black pod, range from USD 250 million to over USD 1 billion, respectively [9].

Rainy season and high humidity favour pathogen sporulation leading to rapid disease progression and production of oospores. Disease spread from the soil into the canopy is often initiated through rain splash. Once the roots, leaves, and fruits in the lower canopy are infected, the pathogen quickly spreads to the upper canopy by insects, wind, and through wind-driven aerosols [7,38]. Additionally, transport of infected nursery plants, improper disposal of infected material, irrigation with zoospore-contaminated water, changing temperatures, and global trade, all contribute to the spread of P. palmivora. This makes it a serious threat to the economy of many developing countries, where cultivation of highly productive perennial crops is intensifying. 
The broad host range of P. palmivora has enabled research using model plants such as Medicago truncatula [39], Hordeum vulgare (barley) [40], and Nicotiana benthamiana [41], moving forward the characterization of the molecular mechanisms involved in P. palmivora colonization. Notably, the process of root colonization by this pathogen is used to study similarities and differences between pathogenicity and symbiosis at the molecular level [42]. Publically available genomic resources are currently limited, which impairs research progresses.

\section{Phytophthora ramorum - the sudden oak death pathogen}

Phytophtora ramorum is a devastating oomycete pathogen that causes sudden oak death disease [43]. $P$. ramorum has a wide host range, affecting more than 100 plant species from 40 different genera. These include environmentally and economically important tree species such as oaks, tanoaks, rhododendron, European beech, Japanese larch, and many woody ornamental plants [43-45]. Disease symptoms are host specific, but can vary from necrotic lesions in leaves, to shoot dieback, to bleeding cankers on the stem [46, 47].

In Europe, P. ramorum is mainly present in ornamental nurseries or gardens, however, in the UK this pathogen has caused significant tree losses and landscape-scale epidemics [44]. Despite the known reports of P. ramorum in Europe [48] and North America [49-52] predictive models suggests that the pathogen might be adapted to larger areas in Africa, Australasia and South America. Therefore, potential of invasion and further spread of the pathogen is possible [53]. In addition, given that diagnosis is primarily based on visual inspection, disease symptoms can be masked by agrochemicals, increasing the likelihood of pathogen intrusion into susceptible areas by the ornamental plant trade market [54].

P. ramorum occurs as four clonal lineages [55] that have resulted in the emergence of new diseases in forest ecosystems within Europe and the US $[48,50,56]$. The P. ramorum genome was sequenced in 2006, a few years after the pathogen was first detected, providing novel insights into its biology [57]. Recent genome sequencing of additional isolates provided additional genetic information to track the spread of the pathogen [58]. However, our understanding of its emergence and adaptation remains relatively limited [59].

\section{Plasmopara obducens - the downy mildew of Impatiens species}

Plasmopara obducens is an obligate biotrophic pathogen of horticultural plants from the Impatiens genus. It causes the Impatiens downy mildew foliar disease, which results in wilted and defoliated plants that die within weeks of disease onset [60]. Commercially grown varieties of Impatiens walleriana are susceptible to $P$. obducens, making P. obducens a clear and present threat to the cultivation of Impatiens spp. worldwide [61]. Within the past decade, outbreaks have been reported in North America [62, 63], Hawaiian Islands [64], Europe [65-67], Asia [60], and Australia [68]. Such epidemics were associated with important economic losses [64]. In the US, the spread of $P$. obducens caused great concern and resulted in the establishment of a research consortium [69]. Cultural practices and chemical applications limit the spread of the disease, however, they are not permanent solutions, as mefenoxam-insensitive P. obducens isolates have already been identified [69]. Additionally, P. obducens is a persistent pathogen; i.e. its ability to spread by wind and survive in soil means disease eradication will be difficult.

The lack of information on the genetics and the structure of P. obducens populations, as well as on the factors 
that led to the establishment of global epidemics, impair the development of effective mitigation strategies. To fill this knowledge gap. Salgado-Salazar et al. [70] recently released a draft genome sequence of $P$. obducens, along with a set of genetic markers. These molecular resources may help in determining both the population structure and genetic factors that control infection processes.

\section{Aphanomyces invadans - the fish epizootic ulcerative syndrome pathogen}

Aphanomyces invadans causes Epizootic Ulcerative Syndrome, a fish disease listed in the World Organisation for Animal Health website (http://www.oie.int/en). A. invadans is pathogenic on several economically important fish, including carp, perch, tilapia, snakeheads, salmonids, and estuarine fish species [71-73]. It was first reported from farmed ayu, Plecoglossus altivelis, in 1971 in Japan [74]. Since then it has spread rapidly throughout Asia and into some areas of Africa.

A. invadans has been responsible for large-scale mortalities of farmed and wild fish in more than 20 countries across four continents [75]. In Asia and Africa, the disease has negatively impacted the livelihood of fish farmers and fishermen and, in some cases threatened the sustainable food supply for local populations, who depend on fish as a relatively affordable source of animal protein [72]. Experimental infection studies have demonstrated that $A$. invadans can produce severe pathological changes in several European salmonid and catfish species [76]. Hence, it is possible that it could cause serious problems in European tilapia, salmon and trout aquaculture industries and in numerous native and wild fish species.

Despite its economic and social importance, little is known about the biology of the A. invadans pathogen. In an effort to address this gap of knowledge, the first draft genome sequence has been completed at The Broad Institute (http://www.ebi.ac.uk/ena/data/view/GCA_000520115). These sequences will enable studies on the biology, evolution, biodiversity, genetics, virulence/pathogenicity, and biochemistry of A. invadan.

\section{Saprolegnia parasitica - the saprolegniosis water mould}

Saprolegnia parasitica causes saprolegniosis on various fish species. In addition to fish, species of amphibians [77], crustaceans [78] and aquatic insects [79] are also highly susceptible to saprolegniosis. There is conclusive evidence that show that Saprolegnia species are major killers of populations of amphibians globally, threatening some already highly endangered species [80-82]. S. parasitica is a major problem in the fish farming industry in Europe, Chile, Canada, and Asia. At least 10\% of all hatched salmon [83] and over 10\% of all eggs succumb to Saprolegnia infections according to estimates $(4,13)$.

Until 2002, S. parasitica was kept under control with applications of malachite green. However, the use of malachite green has been banned worldwide due to its toxicity [84-86], resulting in a dramatic resurgence of Saprolegnia infections in salmon aquaculture. At present, fish farmers are struggling to control this pathogen. Current control methods involve treatments with formalin-based products, which are also expected to be banned in the EU in the very near future [87-89]. Therefore, sustainable prevention and control measures are desperately needed. 
Recent studies have elucidated an induced native immune response and a suppressed adaptive immune response in fish infected by S. parasitica [90]. In addition to distinct biochemical pathways that were described during fish-Saprolegnia interaction to establish infection [91], the genome sequence of S. parasitica [92, 93]-has also shed light on the molecular mechanisms of infection, broadening our understanding of infection mechanisms.

\section{Halioticida noduliformans - the abalone tubercle mycosis pathogen}

Halioticida noduliformans is a marine pathogen of abalone (Haliotis sp.), on which it causes abalone tubercle mycosis, and mantis shrimp (Oratosquilla oratoria). It is a member of the Haliphthorales, an early diverged lineage in the oomycota phylum [94]. H. noduliformans was first discovered in 2004 in South Africa [95, 96]. H. noduliformans is a threat for abalone in commercial aquaculture, which constitutes more than $93 \%$ of the global abalone market [97].

Between 2004 and 2006, several outbreaks in commercial aquaculture farms in South Africa and Japan caused up to $90 \%$ mortality among spat and up to $30 \%$ mortality among older animals [96, 98]. Pathogen control is challenging [96]. Indeed, single H. noduliformans isolates can infect at least three abalone species from South Africa, Mexico and Japan [96].

Researchers from Japan and South Africa have provided insights into the distribution of $H$. noduliformans outbreaks and the molecular phylogeny of Halioticida species [95, 96, 98, 99]. Additionally, Greeff et al. [100] have established a rapid and sensitive qPCR assay for species-specific detection and quantification of $H$. noduliformans in abalone tissue. However, important resources like genome sequences and gene expression data are lacking. Identification of natural hosts and determining whether these hosts act as reservoirs for $H$. noduliformans will be vital to successfully control this disease.

\section{Tackling emerging oomycete threats}

Outbreaks caused by oomycete diseases are a clear and present threat to food security and to natural ecosystems. Although there is a general awareness about these outbreaks, there are gaps in the community capacity to deliver effective short- and long-term response plans. Research showed that oomycetes evolved the ability to infect plants and animals independently of other eukaryotic microbes, and therefore likely developed unique mechanisms of pathogenicity [101]. Last decades have seen significant progress in understanding the biology and the molecular basis of host infection by oomycete pathogens. Notably, genomic studies have revealed fundamental concepts that link genome architecture, pathogenicity related proteins and evolution, key factors that drive disease emergence and pathogen success [22]. Here, we highlight five main research areas that need to be sustained or reinforced to help us tackle emerging and reemerging oomycete threats:

1. GENOMIC RESOURCES - Sequencing of plant oomycetes have pioneered our understanding of pathogenicity and have provided downstream tools that are essential for mechanistic research. In 
addition, as more genomes are sequenced, comparative genomic studies help elucidating infection mechanisms across multiple isolates and species, providing critical information on conserved infection strategies. Oomycete pathogenomics have greatly impacted our approach of plant disease resistance breeding. Indeed, effector proteins turned out to be useful tools for probing plant germplasm for new resistance traits, and can be used in pathogen-informed resistance breeding programs. For animal pathogen oomycetes, limited genomic resources are available at the moment (Table 1). More efforts are needed for identifying pathogen proteins that manipulate host immune systems, as these will allow for the selection and testing of suitable antigens, which may result in the development of vaccines [102].

2. GENETIC MANIPULATION OF HOSTS AND PATHOGENS - Host genetic improvement can be accomplished by precise genome editing techniques, such as the CRISPR/Cas-9 technology [103]. CRISPR/Cas-9 was successfully implemented in tomato to enhance resistance against an oomycete pathogen [104]. To date, mechanistic studies dissecting oomycete-host interactions have been limited to genetic manipulation of the host species due to the lack of efficient gene replacement methods in oomycetes. Recently, Fang and Tyler [105] implemented the CRISPR/Cas9 system in oomycetes and were able to rapidly and efficiently edit the Phytophthora sojae genome. Further implementation of reverse genetic tools in other oomycete species are now needed.

SURVEILLANCE - Surveillance consists of the assessment of disease incidence and virulence characterization (via pathotype surveys). In agriculture, pathogen surveillance is crucial to establish national and international policies, government investment, and strategies in plant protection, plant breeding, seed distribution and pathology. Surveillance remains a critical aspect of disease control, since understanding the pathogen population allows rapid deployment of control methods. In addition to managed agricultural ecosystems, pathogen surveillance should also include natural habitats and potential reservoirs, as these areas generate new inoculum for re-infection.

We have entered a new era in incursion reporting, where social media provide an efficient and rapid platform for data dissemination and collaborative efforts to tackle new disease emergence and spread. By communicating disease significance to the public and building up awareness of these destructive diseases, a community effort for surveillance can be achieved. This was successfully demonstrated in Australia, after the incursion of Myrtle rust [106] and in the recent actions surrounding the outbreak of wheat blast in Bangladesh [107]. Websites such as http://rusttracker.cimmyt.org and http://euroblight.net are great examples of successful first steps to coordinating global disease surveillance efforts.

3. FIELD PATHOGENOMICS - In addition to tracking movement and variation of pathogens (surveillance), tackling emerging diseases will not be successful without concurrently understanding the genetics of host resistance. Field pathogenomics adds highly informative data to surveillance 
surveys by enabling the rapid evaluation of pathogen population structure and host genotype [108]. This was already successfully implemented with oomycete and fungal pathogens of potato and wheat crops, and will be applicable to other pathogens as more genomic information is generated $[32,109]$.

4. DATABASES - Committing to long-term data recording, linkage between databases, free flow of information, and faster exchange of information are necessary for updating epidemiological data. Data should be made rapidly and publically available to maximize the combined and coordinated efforts of the scientific community. For instance, scientists recently released websites to share sequencing data generated as an immediate response to outbreaks such as Ash Dieback (https://geefu.oadb.tsl.ac.uk/), Wheat Yellow Rust in the UK (http://yellowrust.com/), and Wheat Blast in Bangladesh (http://s620715531.websitehome.co.uk/owb/?page_id=61). Additionally, social media websites, such as Plant Village (https://www.plantvillage.org), allow for free sharing of crop diseases information in real time. These websites not only become platforms for scientists to interact, establish collaborations, and coordinate among themselves, but also provide information for the general public and farmers to directly follow and participate in research efforts. They allow the world to connect, share and collectively find solutions to emerging oomycete threats.

Fighting agriculturally important pathogens is a long-term ongoing battle. Just like the constantly morphing flu virus, oomycete pathogens continuously evolve new races to evade host resistance. Agricultural scientists, veterinarians, breeders, and farmers need to remain vigilant and work together in reporting and tackling of oomycete pathogens to achieve successful control. 


\section{Additional Information}

Acknowledgments

We thank Doug Caldwell for inspiring us to select P. obducens.

Authors' Contributions

SK outlined the article. All authors were assigned sections of the article and drafted the associated text. LD and SK oversaw the revisions.

\section{Competing Interests}

We have no competing interests.

\section{Funding}

The Kamoun Lab is funded by the Biotechnology and Biological Sciences Research Council, the European Research Council, and the Gatsby Charitable Foundation. Ronny Kellner is funded by CEPLAS - Cluster of Excellence on Plant Sciences (EXC 1028). Juan Carlos De la Concepcion is funded by The John Innes Foundation. 


\section{References}

[1] Baldauf, S.L., Roger, A.J., Wenk-Siefert, I. \& Doolittle, W.F. 2000 A kingdom-level phylogeny of Eukaryotes based on combined protein data Science 290, 972-977.

[2] Beakes, G.W., Glockling, S.L. \& Sekimoto, S. 2012 The evolutionary phylogeny of the oomycete "fungi". Protoplasma 249, 3-19. (doi:10.1007/s00709-011-0269-2).

[3] Dieguez-Uribeondo, J., Garcia, M.A., Cerenius, L., Kozubikova, E. Ballesteros, I., Windels, C., Weiland, J., Kator, H., Soderhall, K. \& Martin, M.P. 2009 Phylogenetic relationships among plant and animal parasites, and saprotrophs in Aphanomyces (Oomycetes). Fungal Genet Biol 46, 365-376. (doi:10.1016/j.fgb.2009.02.004)

[4] van West, P. 2006 Saprolegnia parasitica, an oomycete pathogen with a fishy appetite: new challenges for an old problem. Mycologist 20, 99-104

[5] Kamoun, S. \& Smart, C.D. 2005 Late blight of potato and tomato in the genomics era. Plant Disease 89, 692-699.

[6] Kamoun, S. 2003 Molecular Genetics of Pathogenic Oomycetes. Eukaryotic Cell 2, 191-199. (doi: 10.1128/EC.2.2.191-199.2003)

[7] Erwin, D.C. \& Ribeiro, O.K. 1996 Phytophthora Diseases Worldwide 562. [8] Haas, B.J., Kamoun, S., Zody, M.C., Jiang, R.H., Handsaker, R.E., Cano, L.M., Grabherr, M., Kodira, C.D., Raffaele, S., Torto-Alalibo, T., et al. 2009 Genome sequence and analysis of the Irish potato famine pathogen Phytophthora infestans. Nature 461, 393-398. (doi:10.1038/nature08358).

[9] Drenth, A. \& Guest, D.I. 2013 Phytophthora palmivora in tropical tree crops. In Phytophthora: A Global Perspective (ed. L. KH), p. 187. Wallingford, U.K. , CABI.

[10] Rizzo, D.M., Garbelotto, M. \& Hansen, E.M. 2005 Phytophthora ramorum integrative research and management of an emerging pathogen in California and Oregon forests. Annu Rev Phytopathol 43, 309-335. (doi:10.1146/annurev.phyto.42.040803.140418).

[11] Agrios, G.N. 2004 Plant Pathology. 5th ed. San Diego, CA, Academic; 952

[12] Lévesque, C.A., Brouwer, H., Cano, L., Hamilton, J.P., Holt, C., Huitema, E., Raffaele, S., Robideau, G.P., Thines, M., Win, J., et al. 2010 Genome sequence of the necrotrophic plant pathogen Pythium ultimum reveals original pathogenicity mechanisms and effector repertoire. Genome Biol 11, 1-22. (doi:10.1186/gb-2010-11-7-r73)

[13] Phillips, A.J., Anderson, V.L., Robertson, E.J., Secombes, C.J. \& van West, P. 20008 New insights into animal pathogenic oomycetes. Trends in Microbiology 16, 13-19.

[14] FAO. 2012 The State of World Fisheries and Aquaculture 2012. (p. 209. Rome.

[15] Martini, R. \& Lindberg, C. 2013 Fishing for Tomorrow: Managing fisherie for sustainable development. In Copherence for development (ed. OECD). UK.

[16] van West, P. \& Beakes, G.W. 2014 Animal pathogenic oomycetes. Fungal Biology 118, 525-526. (doi:10.1016/j.funbio.2014.05.004).

[17] Thines, M. 2014 Phylogeny and evolution of plant pathogenic oomycetesa global overview. . European Journal of Plant Pathology, 138, 431-447. (doi:http://doi.org/10.1007/s10658-013-0366-5).

[18] McDonald, B.A. \& Linde, C. 2002 Pathogen population genetics, evolutionary potential, and durable resistance

$$
\begin{array}{ll}
\text { Annu } & \text { Rev Phytopathol 40, } \\
\text { ://doi.org/10.1146/annurev.phyto.40.120501.101443). }
\end{array}
$$

349-379

(doi:http://doi.org/10.1146/annurev.phyto.40.120501.101443).

[19] Bozkurt, T.O., Schornack, S., Banfield, M.J. \& Kamoun, S. 2012 Oomycetes, effectors, and all that jazz. Current opinion in plant biology $\mathbf{1 5}$ 483-492. (doi:doi:10.1016/j.pbi.2012.03.008).

[20] Schornack, S., Huitema, E., Cano, L., Bozkurt, T.O., Oliva, R., van Damme, M., ZSchqizer, S., Raffaele, S., Chaparro-Garcia, A., Farrer, R., et al. 2009 Ten things to know about oomycete effectors. Mol Plant Pathol 10, 795803. (doi:10.1111/j.1364-3703.2009.00593.x).

[21] Raffaele, S. \& Kamoun, S. 2012 Genome evolution in filamentous plan pathogens: why bigger can be better. . Nature Reviews Microbiology 10, 417 430. (doi:http://doi.org/10.1038/nrmicro2790).

[22] Dong, S., Raffaele, S. \& Kamoun, S. 2015 The two-speed genomes of filamentous pathogens: waltz with plants. Curr Opin Genet Dev 35, 57-65. (doi:10.1016/j.gde.2015.09.001)

[23] Daggett SS, Knighton JE \& CD., T. 1995 Polyploidy among isolates of Phytophthora infestans from Eastern Germany. Journal of Phytopathology 143 , 419-422. (doi:10.1111/j.1439-0434.1995.tb00286.x).

[24] Yoshida, K., Schuenemann, V.J., Cano, L.M., Pais, M., Mishra, B., Sharma, R., Lanz, C., Martin, F.N., Kamoun, S., Krause, J., et al. 2013 The rise and fall of the Phytophthora infestans lineage that triggered the Irish potato famine. eLife 2, e00731. (doi:http://doi.org/10.7554/eLife.00731)

[25] Hamed, B.H. \& Gisi, U. 2013 Generation of pathogenic F1 progeny from crosses of Phytophthora infestans isolates differing in ploidy. Plant Patholog. 62, 708-718.

[26] Li, Y., Zhou, Q., Qian, K., van der Lee, T. \& Huang, S.W. 2015 Successfu asexual lineages of the Irish potato Famine pathogen are triploid. bioRxiv 024596. (doi:http://dx.doi.org/10.1101/024596)

[27] Haverkort, A.J., Boonekamp, P.M., Hutten, R., Jacobsen, E., Lotz, L.A.P., Kessel, G.J.T., Visser, R.G.F. \& van der Vossen, E.A.G. 2008 Societal costs of late blight in potato and prospects of durable resistance through cisgenic modification. Potato Research 51, 47-57.

[28] Fisher, M.C., Henk, D.A., Briggs, C.J., Brownstein, J.S., Madoff, L.C., McCraw, S.L. \& Gurr, S.J. 2012 Emerging fungal threats to animal, plant and ecosystem health. Nature 484, 186-194. (doi:10.1038/nature10947).
[29] Fry, W.E., Birch, P.R., Judelson, H.S., Grunwald, N.J., Danies, G., Everts, K.L., Gevens, A.J., Gugino, B.K., Johnson, D.A., Johnson, S.B., et al. 2015 Five reasons to consider Phytophthora infestans a reemerging pathogen. Phytopathology 105, 966-981. (doi:10.1094/PHYTO-01-15-0005-FI).

[30] Kato, M., Mizubuti, E.S., Goodwin, S.B. \& Fry, W.E. 1997 Sensitivity to Protectant Fungicides and Pathogenic Fitness of Clonal Lineages of Phytophthora infestans in the United States. Phytopathology 87, 973-978. (doi:10.1094/PHYTO.1997.87.9.973).

[31] Fry, W. 2008 Phytophthora infestans: the plant (and R gene) destroyer. Mol Plant Pathol 9, 385-402. (doi:10.1111/j.1364-3703.2007.00465.x).

[32] Cooke, D.E., Cano, L.M., Raffaele, S., Bain, R.A., Cooke, L.R., Etherington, G.J., Deahl, K.L., Farrer, R.A., Gilroy, E.M., Goss, E.M., et al. 2012 Genome analyses of an aggressive and invasive lineage of the Irish potato famine pathogen. PLoS Pathog 8, e1002940. (doi:10.1371/journal.ppat.1002940).

[33] Fry, W.E., McGrath, M.T., Seaman, A., Zitter, T.A., McLeod, A., Danies G., Small, I.M., Myers, K., Everts, K., Gevens, A.J., et al. 2013 The 2009 late blight pandemic in the Eastern United States - causes and results. Plant Disease 97, 296-306. (doi:10.1094/pdis-08-12-0791-fe).

[34] Harbaoui, K., Hamada, W., Li, Y., Vleeshouwers, V.G.A.A. \& van der Lee T. 2014 Increased difficulties to control late blight in Tunisia are caused by a genetically diverse Phytophthora infestans population next to the clonal lineage NA-01. Plant Disease 98, 898-908. (doi:10.1094/pdis-06-13-0610-re).

[35] Chowdappa, P., Kumar, N.B.J., Madhura, S., Kumar, M.S.P., Myers, K.L., Fry, W.E., Squires, J.N. \& Cooke, D.E.L. 2013 Emergence of 13_A2 Blue Lineage of Phytophthora infestans was responsible for severe outbreaks of late blight on tomato in South-West India. Journal of Phytopathology 161, 49-58. (doi:10.1111/jph.12031)

[36] Raffaele, S., Win, J., Cano, L.M. \& Kamoun, S. 2010 Analyses of genome architecture and gene expression reveal novel candidate virulence factors in the secretome of Phytophthora infestans. BMC Genomics 11, 637 (doi:10.1186/1471-2164-11-637).

[37] Stassen, J.H. \& van den Ackerveken, G. 2011 How do oomycete effectors interfere with plant life? Current opinion in plant biology 14, 407-414. (doi:doi:10.1016/j.pbi.2011.05.002).

[38] Torres, G.A., Sarria, G.A., Martinez, G., Varon, A., Drenth, A. \& Guest, D.I. 2016 Bud rot caused by Phytophthora palmivora: A destructive emerging

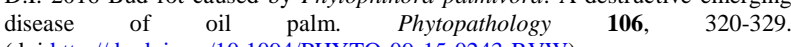
(doi:http://dx.doi.org/10.1094/PHYTO-09-15-0243-RVW).

[39] Rey, T., Chatterjee, A., Buttany, M., Toulotte, J. \& Schornack, S. 2015 Medicago truncatula symbiosis mutants affected in the interaction with a biotrophic root pathogen. New Phytologist 206, 497-500.

[40] Le Fevre, R., O'Boyle, B., Moscou, M.J. \& Schornack, S. 2016 Colonization of barley by the broad-host hemibiotrophic pathogen Phytophthora palmivora uncovers a leaf development dependent involvement of MLO. Mol Plant Microbe Interact. (doi:10.1094/MPMI-12-15-0276-R).

[41] Chaparro-Garcia, A., Wilkinson, R.C., Gimenez-Ibanez, S., Findlay, K. Coffey, M.D., Zipfel, C., Rathjen, J.P., Kamoun, S. \& Schornack, S. 2011 The receptor-like kinase SERK3/BAK1 is required for basal resistance against the late blight pathogen Phytophthora infestans in Nicotiana benthamiana. PLoS One 6, e16608. (doi:10.1371/journal.pone.0016608).

[42] Wang, E., Schornack, S., Marsh, J.F., Gobbato, E., Schwessinger, B., Eastmond, P., Schultze, M., Kamoun, S. \& Oldroyd, G.E. 2012 A common signaling process that promotes mycorrhizal and oomycete colonization of plants. Curr Biol 22, 2242-2246. (doi:10.1016/j.cub.2012.09.043).

[43] Grünwald, N.J., Goss, E.M. \& Press, C.M. 2008 Phytophthora ramorum: a pathogen with a remarkably wide host range causing sudden oak death on oaks and ramorum blight on woody ornamentals. Molecular Plant Pathology 9, 729740. (doi:10.1111/j.1364-3703.2008.00500.x).

[44] Brasier, C. \& Webber, J. 2010 Plant pathology: Sudden larch death. Nature 466, 824-825.

[45] Grünwald, N.J., Garbelotto, M., Goss, E.M., Heungens, K. \& Prospero, S 2012 Emergence of the sudden oak death pathogen Phytophthora ramorum. $\begin{array}{llll}\text { Trends in } & \text { Microbiology } & \text { 20, } & 131-138\end{array}$ (doi:http://dx.doi.org/10.1016/j.tim.2011.12.006)

[46] Hansen, E.M., Parke, J.L. \& Sutton, W. 2005 Susceptibility of Oregon forest trees and shrubs to Phytophthora ramorum: A comparison of artificial inoculation and natural infection. Plant Disease 89, 63-70. (doi:10.1094/pd-890063)

[47] Rizzo, D.M., Garbelotto, M. \& Hansen, E.M. 2005 Phytophthora ramorum: integrative research and management of an emerging pathogen in California and Oregon forests. Аnnu Rev Phytopathol 43, 309-335. (doi:10.1146/annurev.phyto.42.040803.140418)

[48] Vercauteren, A., Dobbelaere, I., Bockstaele, E., Maes, M. \& Heungens, K. 2010 Genotypic and phenotypic characterization of the European A2 isolates of Phytophthora ramorum. European Journal of Plant Pathology 129, 621-635. (doi:10.1007/s10658-010-9727-5).

[49] Goss, E.M., Carbone, I. \& Grunwald, N.J. 2009 Ancient isolation and independent evolution of the three clonal lineages of the exotic sudden oak death pathogen Phytophthora ramorum. Mol Ecol 18, 1161-1174. (doi:10.1111/j.1365294X.2009.04089.x).

[50] Goss, E.M., Larsen, M., Chastagner, G.A., Givens, D.R. \& Grunwald, N.J. 2009 Population genetic analysis infers migration pathways of Phytophthora ramorum in US nurseries. PLoS Pathog 5, e1000583. (doi:10.1371/journal.ppat.1000583). 
[51] Ivors, K., Garbelotto, M., Vries, I.D., Ruyter-Spira, C., Te Hekkert, B., Rosenzweig, N. \& Bonants, P. 2006 Microsatellite markers identify three lineages of Phytophthora ramorum in US nurseries, yet single lineages in US forest and European nursery populations. Mol Ecol 15, 1493-1505. (doi:10.1111/j.1365-294X.2006.02864.x).

[52] Mascheretti, S., Croucher, P.J., Kozanitas, M., Baker, L. \& Garbelotto, M 2009 Genetic epidemiology of the sudden oak death pathogen Phytophthora ramorum in California. Mol Ecol 18, 4577-4590. (doi:10.1111/j.1365294X.2009.04379.x).

[53] Ireland, K.B., Hardy, G.E. \& Kriticos, D.J. 2013 Combining inferential an deductive approaches to estimate the potential geographical range of the invasive plant pathogen, Phytophthora ramorum. PLoS One 8, e63508. (doi:10.1371/journal.pone.0063508).

[54] Moslonka-Lefebvre, M., Finley, A., Dorigatti, I., Dehnen-Schmutz, K. Harwood, T., Jeger, M.J., Xu, X., Holdenrieder, O. \& Pautasso, M. 201 Networks in plant epidemiology: from genes to landscapes, countries, an continents. Phytopathology 101, 392-403. (doi:10.1094/PHYTO-07-10-0192).

[55] Van Poucke, K., Franceschini, S., Webber, J.F., Vercauteren, A., Turner J.A., McCracken, A.R., Heungens, K. \& Brasier, C.M. 2012 Discovery of a fourth evolutionary lineage of Phytophthora ramorum: EU2. Fungal Biology 116, 1178-1191. (doi:http://dx.doi.org/10.1016/i.funbio.2012.09.003).

[56] Goss, E.M., Larsen, M., Vercauteren, A., Werres, S., Heungens, K. \& Grünwald, N.J. 2010 Phytophthora ramorum in Canada: Evidence for Migration Within North America and from Europe. Phytopathology 101, 166-171. (doi:10.1094/PHYTO-05-10-0133).

[57] Kamoun, S., Furzer, O., Jones, J.D., Judelson, H.S., Ali, G.S., Dalio, R.J., Roy, S.G., Schena, L., Zambounis, A., Panabieres, F., et al. 2015 The Top 10 oomycete pathogens in molecular plant pathology. Mol Plant Pathol 16, 413 434. (doi:10.1111/mpp.12190).

[58] Mata Saez Lde, L., McCracken, A.R., Cooke, L.R., O'Neill, P., Grant, M. \& Studholme, D.J. 2015 Draft genome sequences of seven isolates of Phytophthora ramorum EU2 from Northern Ireland. Genom Data 6, 191-192. (doi:10.1016/j.gdata.2015.09.009).

[59] Grünwald, N.J. 2012 Genome sequences of Phytophthora enable translational plant disease management and accelerate research. Canadian Journal of Plant Pathology-Revue Canadienne De Phytopathologie 34, 13-19. (doi:10.1080/07060661.2012.664568)

[60] Shen, Y.M., Huang, J.H. \& Liu, H.L. 2013 First report of downy mildew caused by Plasmopara obducens on Impatiens in Taiwan. Plant Disease 97, 1512

[61] Braiser, C.M. 2008 The biosecurity threat to the UK and globa environment from international trade in plants. Plant Pathology 57, 792-808. [62] Wegulo, S.N., Koike, S.T., Vilchez, M. \& Santos, P. 2004 First report of downy mildew caused by Plasmopara obducens on Impatiens in California. Plant Disease 88, 909.

[63] Baysal-Gurel, F., Taylor, N.J., Chatfield, J. \& Miller, S.A. 2012 First report of Impatiens downy mildew caused by Plasmopara obducens in Ohio. Plant Disease 96, 1699.

[64] Crouch, J.A., Ko, M.P. \& Mckenny, J.M. 2014 First report of impatien downy mildew outbreaks caused by Plamopara obducens throughout the Hawai' ian islands. Plant Disease 98, 696.

[65] Lane, C.R., Beales, P.A., O'Neill, T.M., McPherson, G.M., Finlay, A.R., David, J., Constantinescu, O. \& Henricot, B. 2005 First report of Impatiens downy mildew (Plasmopara obducens) in the UK. Plant Pathology 54, 243.

[66] Toppe, B., Brurberg, M.B., Stensvand, A., Herrero, M.L. \& 59:800, P.p 2010 First report of Plasmopara obducens (downy mildew) on Impatien walleriana in Norway. Plant Pathology 59, 800.

[67] Bulajic, A., Vucurovic, A., Stankovic, I., Ristic, D., Jovic, J., Stojkovic, B. \& Krstic, B. 2011 First report of Plasmopara obducens on Impatiens walleriana in Serbia. Plant Disease 95, 491

[68] Cunnington, J.H., Aldaoud, R., Loh, M., Washington, W.S. \& Irvine, G. 2008 First record of Plasmopara obducens (downy mildew) on impatiens in Australia. Plant Pathology 57, 371.

[69] Daughtry, M. \& Cristi, P. 2014 Impatiens: Is there life after downy mildew? (American Hort News.

[70] Salgado-Salazar, C., Rivera, Y., Veltri, D. \& Crouch, J.A. 2015 Polymorphic SSR markers for Plasmopara obducens (Peronosporaceae), the newly emergent downy mildew pathogen of Impatiens (Balsaminaceae). Appl Plant Sci 3. (doi:10.3732/apps.1500073)

[71] Lilley, J.H., Hart, D., Panyawachira, V., Kanchanakhan, S., Chinabut, S. Soderhall, K. \& Cerenius, L. 2003 Molecular characterization of the fishpathogenic fungus Aphanomyces invadans. Journal of Fish Diseases 26, $263-$ 275 .

[72] Oidtmann, B. 2012 Review of biological factors relevant to import risk assessments for epizootic ulcerative syndrome (Aphanomyces invadans). Transbound Emerg Dis 59, 26-39. (doi:10.1111/j.1865-1682.2011.01241.x).

[73] Vandersea, M.W., Litaker, R.W., Yonnish, B., Sosa, E., Landsberg, J.H., Pullinger, C., Moon-Butzin, P., Green, J., Morris, J.A., Kator, H., et al. 2006 Molecular assays for detecting Aphanomyces invadans in ulcerative mycotic fish lesions. Appl Environ Microbiol 72, 1551-1557. (doi:10.1128/AEM.72.2.15511557.2006).

[74] Egusa, S. \& Masuda, N. 1971 A new fungal disease of Plecoglossus altivelis. Fish Pathology 6, 41 - 46 (in Japanese).

[75] Pradhan, P.K., Rathore, G., Sood, N., Swaminathan, T.R., Yadav, M.K., Verma, D.K., Chaudhary, D.K., Abidi, R., Punia, P. \& Jena, J.K. 2014 Emergence of epizootic ulcerative syndrome: large-scale mortalities of cultured and wild fish species in Uttar Pradesh, India. Current Science 106, 1711-1718.

[76] Oidtmann, B., Steinbauer, P., Geiger, S. \& Hoffmann, R.W. 2008 Experimental infection and detection of Aphanomyces invadans in European catfish, rainbow trout and European eel. Dis Aquat Organ 82, 195-207. (doi:10.3354/dao01973)

[77] Blaustein, A.R., Grant Hokit, D., O'Hara, R.K. \& Holt, R.A. 1994 Pathogenic fungus contributes to amphibian losses in the pacific northwest.
Biological Conservation 67, 251-254. (doi:http://dx.doi.org/10.1016/00063207(94)90616-5)

[78] Dieguez-Uribeondo, J., Cerenius, L. \& Soderhall, K. 1994 Saprolegnia parasitica and its virulence on three different species of freshwater crayfish Aquaculture 120, 219-228. (doi:http://dx.doi.org/10.1016/0044-8486(94)900809).

[79] Sarowar, M.N., van den Berg, A.H., McLaggan, D., Young, M.R. \& van West, P. 2013 Saprolegnia strains isolated from river insects and amphipods are broad spectrum pathogens. Fungal Biology 117, 752-763. (doi:10.1016/j.funbio.2013.09.002).

[80] Fernández-Benéitez, M.J., Ortiz-Santaliestra, M.E., Lizana, M. \& DiéguezUribeondo, J. 2011 Differences in susceptibility to Saprolegnia infections among embryonic stages of two anuran species. Oecologia 165, 819-826. (doi:10.1007/s00442-010-1889-5).

[81] Fernández-Benéitez, M.J., Ortiz-Santaliestra, M.E., Lizana, M. \& DiéguezUribeondo, J. 2008 Saprolegnia diclina: another species responsible for the emergent disease 'Saprolegnia infections' in amphibians. FEMS Microbiol Let 279, 23-29. (doi:10.1111/j.1574-6968.2007.01002.x).

[82] Kiesecker, J.M., Blaustein, A.R. \& Miller, C.L. 2001 Transfer of a pathogen from fish to amphibians. Conservation Biology 15, 1064-1070. (doi:10.1046/j.1523-1739.2001.0150041064.x).

[83] Phillips, A.J., Anderson, V.L., Robertson, E.J., Secombes, C.J. \& van West, P. 2008 New insights into animal pathogenic oomycetes. Trends in Microbiology 16, 13-19. (doi:10.1016/j.tim.2007.10.013).

[84] Alderman, D.J. \& Polglase, J.L. 1984 A comparative investigation of the effects of fungicides on Saprolegnia parasitica and Aphanomyces Astaci. Transactions of the British Mycological Society 83, 313-318. (doi:10.1016/S0007-1536(84)80153-9).

[85] Meyer, F.P. \& Jorgenson, T.A. 1983 Teratological and other effects of malachite green on the development of rainbow trout and rabbits. Transaction of the American Fish Society 112, 818-824. (doi:10.1577/15488659(1983)112<818:TAOEOM>2.0.CO;2).

[86] Srivastava, S., Sinha, R. \& Roy, D. 2004 Toxicological effects of malachite green. Aquatic Toxicology 66, 319-329. (doi:10.1016/j.aquatox.2003.09.008).

[87] Magaraggia, M., Faccenda, F., Gandolfi, A. \& Jori, G. 2006 Treatment of microbiologically polluted aquaculture waters by a novel photochemical technique of potentially low environmental impact. Journal Environmental Monitorng 8, 923-931. (doi:10.1039/B606975D)

[88] Marking, L.L., Rach, J.J. \& Schreier, T.M. 1994 Evaluation of Antifungal Agents for Fish Culture. The Progressive Fish Culturist 56, 225-231. (doi:10.1577/1548-8640(1994)056<0225:AFSEOA>2.3.CO;2)

[89] Burka, J.F., Hammell, K.L., Horsberg, T.E., Johnson, G.R., Rainnie, D.J. \& Speare, D.J. 1997 Drugs in salmonid aquaculture - A review. Journal of Veterinary Pharmacology and Therapeutics 20, 333-349. (doi:10.1046/j.13652885.1997.00094.x)

[90] Belmonte, R., Wang, T., Duncan, G.J., Skaar, I., Mélida, H., Bulone, V., van West, P. \& Secombes, C.J. 2014 Role of pathogen-derived cell wall carbohydrates and prostaglandin E2 in immune response and suppression of fish immunity by the oomycete Saprolegnia parasitica. Infection and Immunity $\mathbf{8 2}$ 4518-4529. (doi:10.1128/IAI.02196-14).

[91] Wawra, S., J., B., Durward, E., de Bruijn, I., Minor, K.L., Matena, A., Lobach, L., Whisson, S.C., Bayer, P., Porter, A.J., et al. 2012 Host-targeting protein 1 (SpHtp1) from the oomycete Saprolegnia parasitica translocates specifically into fish cells in a tyrosine-Osulphate- dependent manner. Proceeding of the National Academy of Sciences 109, 2096-2101. (doi:10.1073/pnas.1113775109).

[92] Wawra, S., Belmonte, R., Löbach, L., Saraiva, M., Willems, A. \& van West, P. 2012 Secretion, delivery and function of oomycete effector proteins. Current Opinion in Microbiology 15, 685-691. (doi:10.1016/j.mib.2012.10.008)

[93] Jiang, R.H., de Bruijn, I., Haas, B.J., Belmonte, R., Lobach, L., Christie, J., van den Ackerveken, G., Bottin, A., Bulone, V., Diaz-Moreno, S.M., et al. 2013 Distinctive expansion of potential virulence genes in the genome of the oomycete fish pathogen Saprolegnia parasitica. PLoS Genet 9, e1003272. (doi:10.1371/journal.pgen.1003272)

[94] Beakes, D., Honda, D. \& Thines, M. 2014 Systematics of the Straminipila: Labyrinthulomycota, Hyphochytriomycota and Oomycota. In The Mycota Systematics and Evolution Part A (eds. M. DJ \& S. JW), pp. 39-97, 2nd ed. Berlin Heidelberg, Springer.

[95] Atami, H., Muraosa, Y. \& Hatai, K. 2009 Halioticida Infection Found in Wild Mantis Shrimp Oratosquilla oratoria in Japan. Fish Pathology 44, 145150. (doi:http://doi.org/10.3147/jsfp.44.145).

[96] Muraosa, Y., Morimoto, K., Sano, A., Nishimura, K. \& Hatai, K. 2009 A new peronosporomycete, Halioticida noduliformans gen. et sp. nov., isolated from white nodules in the abalone Haliotis spp. from Japan. Mycoscience 50, 106-115. (doi:http://doi.org/10.1007/s10267-008-0462-0).

[97] Cook, P.A. 2014 The Worldwide Abalone Industry. Modern Economy 05 , 1181-1186. (doi:10.4236/me.2014.513110).

[98] Macey, B.M., Christison, K.W. \& Mouton, A. 2011 Halioticida noduliformans isolated from cultured abalone (Haliotis midae) in South Africa. Aquaculture 315, 187-195. (doi:10.1016/j.aquaculture.2011.02.004).

[99] Hatai, K. 2012 Diseases of Fish and Shellfish Caused by Marine Fungi. In Biology of Marine Fungi (ed. R. C), pp. 159-171. Berlin Heidelberg, Springer. [100] Greeff, M.R., Christison, K.W. \& MacEy, B.M. 2012 Development and preliminary evaluation of a real-time PCR assay for Halioticida noduliforman in abalone tissues. Dis Aquat Organ 99, 103-117. (doi:http://doi.org/10.3354/dao02468).

[101] Jiang, R.H.Y. \& Tyler, B.M. 2012 Mechanisms and evolution of virulence in oomycetes. Annu Rev Phytopathol 50, 295-318. (doi:http://doi.org/10.1146/annurev-phyto-081211-172912).

[102] Minor, K., Anderson, V.L., Davis, K., van den Berg, A.H., Christie, J., Löbach, L., Faruk, A.R., Wawra, S., Secombes, C.J. \& van West, P. 2014 A 
putative serine protease, SpSsp1, from Saprolegnia parasitica is recognised by sera of rainbow trout, Oncorhynchus mykiss. Fungal Biology 118, 630-639.

[103] Belhaj, K., Chaparro-Garcia, A., Kamoun, S., Patron, N.J. \& Nekrasov, V. 2014 Engineering plant genomes with CRISPR/Cas9. . Current Opinion in Biotechnology 32, 76-84. (doi: http://dx.doi.org/10.1016/j.copbio.2014.11.007 ). [104] de Toledo Thomazella, D.P., Brail, Q., Dahlbeck, D. \& Staskawicz, B.J. 2016 CRISPR-Cas9 mediated mutagenesis of a DMR6 ortholog in tomato confers braod-spectrum disease resistance. bioRxiv. (doi:http://dx.doi.org/10.1101/064824).

[105] Fang, Y. \& Tyler, B.M. 2016 Efficient disruption and replacement of an effector gene in the oomycete Phytophthora sojae using CRISPR/cas9. Mol Plant Pathol 17, 127-139. (doi:10.1111/mpp.12318).

[106] Carnegie, A.J. \& Cooper, K. 2011 Emergency response to the incursion of an exotic myrtaceous rust in Australia. Australasian Plant Pathology 40, 346. (doi:doi:10.1007/213313-011-0066-6).

[107] Islam, T., Croll, D., Gladieux, P., Soanes, D., Persoons, A., Bhattacharjee, P., Hossain, S., Gupta, D., Rahman, M.M., Mahboob, M.G., et al. 2016 Emergence of wheat blast in Bangladesh was caused by a South American lineage of Magnaporthe

oryzae.

bioRxiv

(doi:doi: http://dx.doi.org/10.1101/059832.

[108] Derevnina, L. \& Michelmore, R.W. 2015 Wheat rust never sleep but neither do sequencers: will pathogenics transform the way plant disease is managed? Genome Biol 16, 44. (doi:DOI: 10.1186/s13059-015-0615-3).

[109] Hubbard, A., Lewis, C.M., Yoshida, K., Ramirez-Gonzalez, R.H., de Vallavieille-Pope, C., Thomas, J., Kamoun, S., Bayles, R., Uauy, C. \& Saunders, D.G. 2015 Field pathogenomics reveals the emergence of a diverse wheat yellow rust population. Genome Biol 16, 23. (doi:10.1186/s13059-0150590-8).

[110] El-Ganainy, S.M., Tohamy, A.M.M., WAward, M.A., Squires, J.N. \& Cooke, D.E. 2013 The population dynamics of Phytophthora infestans in Egypt. In American Phytopathological Society annual meeting (ed. APS). Austin, Texas.

[111] Tyler, B.M., Tripathy, S., Zhang, X., Dehal, P., Jiang, R.H., Aerts, A., Arredondo, F.D., Baxter, L., Bensasson, D., Beynon, J.L., et al. 2006 Phytophthora genome sequences uncover evolutionary origins and mechanisms of pathogenesis. Science 313, 1261-1266. 


\section{Figure captions}

Figure 1. An emerging clonal lineage reshaped P. infestans populations in Great Britain. (A) Multilocus genotyping of $P$. infestans isolates from 4000 late blight infection sites over 11 years. This survey revealed that the late blight epidemic that started in 2006 was due to the aggressive 13_A2 isolate that became dominant in only three years. The number of surveyed isolates and dominant genotypes of each mating type are indicated. Genotypes with low frequency are grouped as "misc". The shading between bars indicates mating types. (Figure and legend are adapted from [32]). (B) 13_A2 isolate has rapidly spread to other continents and caused devastating economic losses especially in developing countries such as India and Egypt [35]. Dots represent an approximate of sampling sites for years 2013 and 2014 according to EuroBlight data and recent reports [110]. 


\section{Tables}

Table 1. Features of oomycete pathogens highlighted in this paper, including the primary host, genome size,

repetitive DNA content (as a percentage of genome size), number of protein coding genes, percentage of

predicted secreted proteins, and a summary of why the pathogen is a (re)-emerging threat.

\begin{tabular}{|c|c|c|c|c|c|c|}
\hline Pathogen & $\begin{array}{l}\text { Important hosts } \\
\text { (P: Plant, A: Animal) }\end{array}$ & $\begin{array}{l}\text { Common disease name } \\
\text { (host) }\end{array}$ & Why is it a (re)-emerging threat? & $\begin{array}{l}\text { Genome size } \\
(\mathrm{Mb}) \quad(\% \\
\text { repetitive })\end{array}$ & $\begin{array}{l}\text { Protein coding } \\
\text { genes (\% secreted) }\end{array}$ & Ref \\
\hline $\begin{array}{l}\text { Phytophthora } \\
\text { infestans }\end{array}$ & $\mathrm{P}$ - potato, tomato & late blight & $\begin{array}{l}\text { New aggressive genotypes emerged in the } \\
\text { UK (2008 and 2011) and India (2008) }\end{array}$ & $240(7.4)$ & $18,155(8.7)$ & [8] \\
\hline $\begin{array}{l}\text { Phytophthora } \\
\text { palmivora }\end{array}$ & $\begin{array}{l}\mathrm{P}-\text { cocoa, coconut, } \\
\text { pineapple, rubber tree, } \\
\text { papaya, oil palm }\end{array}$ & $\begin{array}{l}\text { bud rot (oil palm), black } \\
\text { pod (cocoa), fruit rot (papaya) }\end{array}$ & $\begin{array}{l}\text { Outbreaks regularly destroy oil palm and } \\
\text { cocoa plantations worldwide }\end{array}$ & $\mathrm{nd}^{* *}(\mathrm{nd})$ & nd (nd) & - \\
\hline $\begin{array}{l}\text { Phytophthora } \\
\text { ramorum }\end{array}$ & $\begin{array}{c}\mathrm{P}-\mathrm{oak}, \quad \text { tanoaks, } \\
\text { rhododendron, beech, larch }\end{array}$ & sudden oak death (oak) & $\begin{array}{l}\text { Outbreaks destroyed forests in North } \\
\text { America and Europe during the last } 20 \text { years }\end{array}$ & $65(17)$ & $14,451(10.5)$ & ${ }^{[111}$ \\
\hline $\begin{array}{l}\text { Plasmopara } \\
\text { obducens }\end{array}$ & P - Impatiens species & Impatiens downy mildew & $\begin{array}{c}\text { Outbreaks occurred in } \text { nurseries } \\
\text { worldwide within the last decade }\end{array}$ & 70 (nd) & nd (nd) & [70] \\
\hline $\begin{array}{l}\text { Aphanomyces } \\
\text { invadens }\end{array}$ & $\begin{array}{l}\text { A - carp, perch, tilapia, } \\
\text { snakeheads, } \\
\text { estuarine }\end{array}$ & $\begin{array}{l}\text { Epizootic } \quad \text { Ulcerative } \\
\text { Syndrome }\end{array}$ & $\begin{array}{l}\text { Regularly kills farmed and wild fish } \\
\text { worldwide, threatening food safety in Asia } \\
\text { and Africa }\end{array}$ & 71 (nd) & 15,248 (nd) & $* * *$ \\
\hline $\begin{array}{l}\text { Saprolegnia } \\
\text { parasitica }\end{array}$ & 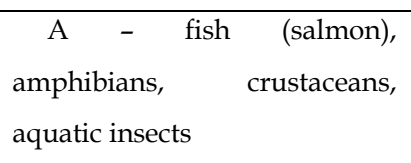 & saprolegniosis & $\begin{array}{l}\text { Threatens to fish farming in Europe, } \\
\text { America, and Asia, as well as endangered } \\
\text { amphibian species worldwide }\end{array}$ & $63(17)$ & $17,065(5.7)$ & [93] \\
\hline $\begin{array}{r}\text { Halioticida } \\
\text { noduliformans }\end{array}$ & A - abalone, mantis shrimp & $\begin{array}{l}\text { abalone tubercle mycosis } \\
\text { (abalone) }\end{array}$ & $\begin{array}{l}\text { Severe outbreaks occurred in South Africa } \\
\text { and Japan between } 2004 \text { and } 2006\end{array}$ & nd (nd) & nd (nd) & - \\
\hline
\end{tabular}

*Including putative effectors

**nd - no data 
***http://www.ebi.ac.uk/ena/data/view/GCA_000520115 